\title{
Tumour morphology of early-onset breast cancers predicts breast cancer risk for first-degree relatives: the Australian Breast Cancer Family Registry
}

\author{
Gillian S Dite ${ }^{1}$, Enes Makalic ${ }^{1}$, Daniel F Schmidt ${ }^{1}$, Graham G Giles ${ }^{1,2}$, John L Hopper ${ }^{1 *}$ and Melissa C Southey ${ }^{3}$
}

\begin{abstract}
Introduction: We hypothesised that breast cancer risk for relatives of women with early-onset breast cancer could be predicted by tumour morphological features.

Methods: We studied female first-degree relatives of a population-based sample of 452 index cases with a first primary invasive breast cancer diagnosed before the age of 40 years. For the index cases, a standardised tumour morphology review had been conducted for all; estrogen (ER) and progesterone receptor (PR) status was available for 401 (89\%), and 77 (17\%) had a high-risk mutation in a breast cancer susceptibility gene or methylation of the BRCA1 promoter region in peripheral blood DNA. We calculated standardised incidence ratios (SIR) by comparing the number of mothers and sisters with breast cancer with the number expected based on Australian incidence rates specific for age and year of birth.
\end{abstract}

Results: Using Cox proportional hazards modelling, absence of extensive sclerosis, extensive intraductal carcinoma, absence of acinar and glandular growth patterns, and the presence of trabecular and lobular growth patterns were independent predictors with between a 1.8- and 3.1-fold increased risk for relatives (all $P<0.02$ ). Excluding index cases with known genetic predisposition or BRCA1 promoter methylation, absence of extensive sclerosis, circumscribed growth, extensive intraductal carcinoma and lobular growth pattern were independent predictors with between a 2.0- and 3.3-fold increased risk for relatives (all $P<0.02$ ). Relatives of the 128 (34\%) index cases with none of these four features were at population risk ( $\mathrm{SIR}=1.03,95 \% \mathrm{Cl}=0.57$ to 1.85 ) while relatives of the 37 (10\%) index cases with two or more features were at high risk ( $\mathrm{SIR}=5.18,95 \% \mathrm{Cl}=3.22$ to 8.33 ).

Conclusions: This wide variation in risks for relatives based on tumour characteristics could be of clinical value, help discover new breast cancer susceptibility genes and be an advance on the current clinical practice of using ER and PR as pathology-based predictors of familial and possibly genetic risks.

\section{Introduction}

While information about breast tumour morphology is used to make important decisions about treatment, it can also be important in assessing breast cancer risk for an affected woman's relatives. In this paper, we look at the extent to which familial risk of breast cancer depends on tumour morphology, an issue of both clinical and aetiological significance.

Female relatives of women with breast cancer are at increased risk of the disease, and it is well-established

\footnotetext{
* Correspondence: j.hopper@unimelb.edu.au

'Centre for Molecular, Environmental, Genetic and Analytic Epidemiology,

The University of Melbourne, Melbourne, VIC, Australia

Full list of author information is available at the end of the article
}

that the magnitude of their risk depends upon the closeness of their relationship to their affected relatives and the number and age at diagnosis of their affected relatives [1-6]. The risk of breast cancer is substantially elevated for women with an affected first-degree relative carrying a high-risk mutation in $B R C A 1$ or $B R C A 2$ [4-6] or a mutation in ATM [7] or TP53 [8-10], but high-risk mutations in these susceptibility genes are rare and explain only approximately $25 \%$ of the familial risk of breast cancer [11].

We recently showed that two breast tumour morphology features, trabecular growth pattern and high mitotic index, were sufficient to identify almost all $B R C A 1$ mutation carriers in our population-based sample of breast

\section{C) Biomed Central}


cancer cases diagnosed before the age of 40 years [12]. We also found that having five or more of nine pre-specified tumour morphology features defined a morphological profile that contained 27 (93\%) of the 29 known BRCA1 mutation carriers [12], and of the 52 with this morphological profile who were not found to carry a germline BRCA1 mutation, 16 (31\%) were found to have methylation of the $B R C A 1$ promoter region in DNA from peripheral blood [13].

Given the importance of tumour morphology features to inform treatment choices and to identify $B R C A 1$ mutation carriers [12] or $B R C A 1$ promoter methylation [13], we are now interested in identifying tumour morphology features that predict familial risk of early-onset breast cancer.

\section{Methods}

\section{Australian Breast Cancer Family Registry}

This study used data and materials from the Australian Breast Cancer Family Registry (ABCFR), which includes a population-based case-control-family study that has been described in detail elsewhere [3,14-16]. Briefly, between 1992 and 1998, index cases were identified using state population-based cancer registries as adult women living in the metropolitan areas of Melbourne and Sydney, who were aged less than 60 years when diagnosed with a histologically confirmed first primary invasive breast cancer. Index cases and participating relatives completed an interviewer-administered risk factor questionnaire and a family history questionnaire that asked for details of any cancer history for themselves and for their first-degree and second-degree relatives [3].

Missing family history data were imputed using a previously developed protocol for the following data items: date of birth, age, vital status, date of death, age at death, date at breast cancer diagnosis and age at breast cancer diagnosis [3,6]. Verification of reported cancers through cancer registries, medical records and death certificates was obtained where possible [3].

Approval for the study was obtained from the Human Research Ethics Committees of the University of Melbourne and the Cancer Councils of Victoria and New South Wales. All participants provided written informed consent prior to participation in the ABCFR.

\section{Tumour morphology review}

Archival tumour blocks were sought for all index cases under the age of 40 years at diagnosis [12], and a validated tumour morphology review was completed by pathologists blinded to the mutation status of the index case $[17,18]$. Briefly, the tumours were typed into primary pattern and secondary pattern using the World Health Organisation breast carcinoma classification with minor modifications as described by Page et al. [19]. Tumour grade was scored using the modified system of Bloom and Richardson by assessing mitotic rate, tubular differentiation and nuclear pleomorphism [19] as applied in Southey et al. [12]. Sclerosis was defined as a central area of fibrosis composed of fibroblasts and/or collagen that is devoid of tumour cells, and labelled extensive if it comprised more than $20 \%$ of the tumour volume.

Estrogen receptor (ER) and progesterone receptor (PR) status was obtained either from immunohistochemical testing of tumour tissue [20] or from histopathology reports held by the cancer registry or a diagnostic laboratory [21].

From the tumour morphology review, the following features were extracted as either absent or present:

Number of mitoses $>50$ (per 10 high powered fields) Nuclear grade - malignant (scored as bland, intermediate, malignant)

Tubule formation $<10$ (scored as $>75,10$ to $75,<10$ ) Syncytical pattern $\geq 75 \%$ (scored as no, yes)

Circumscribed (scored as no, yes)

Pushing margins $>50 \%$ (scored as no, yes)

Lymphocytic Infiltrate I - diffuse (scored as absent/ minimal, border, diffuse)

Lymphocytic infiltrate II - intense (scored as absent/ minimal, moderate, intense)

Glandular growth pattern (primary growth pattern)

Lobular growth pattern (primary or secondary growth pattern)

Trabecular growth pattern (primary or secondary growth pattern)

Tubular growth pattern (primary or secondary growth pattern)

Acinar growth pattern (secondary growth pattern)

Sclerosis - extensive (scored as minimal, extensive)

Extensive intraductal carcinoma - present (scored as absent, present, uncertain)

Necrosis - present (scored as absent, present, uncertain)

Apoptosis - moderate or intense (scored as absent/ minimal, moderate, intense)

Lymphatic invasion - present (scored as absent, present, uncertain)

Note: growth patterns were scored as glandular (primary only), lobular, trabecular, tubular and acinar (secondary only).

\section{Mutation testing for high-risk breast cancer genes}

Testing for high-risk mutations in breast cancer predisposition genes was conducted for all index cases under the age of 40 years at diagnosis and from whom a blood sample had been obtained. Full details of the BRCA1 and $B R C A 2$ mutation testing have been reported elsewhere 
and included: sequencing, protein truncation testing, two-dimensional gel electrophoresis, screening for large genomic alterations, testing for Ashkenazi founder mutations and testing for duplication of exon 13 of BRCA1 $[3,12]$. ATM was tested for the c.7271 T $>\mathrm{G}$ mutation [22-25] and testing for mutations in TP53 was performed by Sanger sequencing and specific screening for larger gene rearrangements [10].

\section{BRCA1 methylation}

Testing for methylation of the promoter region of $B R C A 1$ was conducted for all index cases under the age of 40 years at diagnosis and for whom a pathology review had been conducted [13].

\section{Relatives}

For the present study, mothers and sisters were included if their index case was under the age of 40 years when diagnosed with a histologically confirmed first primary invasive breast cancer and had a pathology review completed. For each relative included in the analyses, the following data were extracted: relationship to the index case; date of birth; vital status; age at interview or death; breast cancer status; and age at diagnosis, if affected.

\section{Statistical methods}

Australian population-based female breast cancer incidence rates, specific for age and year of birth (both in fiveyear groupings), were obtained for 1983 to 2001 and extrapolated to earlier years as described previously [6]. The standardised incidence ratio (SIR) was estimated by comparing the observed number of mothers and sisters with breast cancer with the number expected from applying Australian population-based female breast cancer incidence rates specific for age and year of birth (both in fiveyear groupings). The ratio of SIRs and 95\% confidence intervals $(\mathrm{CI})$ were calculated using the method described by Breslow and Day [[26], pages 94-95]. Estimates of hazard ratios (HR) were obtained from Cox proportional hazards models and robust estimates of standard errors were obtained to account for clustering within families. We used the likelihood ratio test to identify best fitting models by forward selection and confirmed by backwards elimination, with a nominal $P$-value of 0.05 as a threshold, and to test the null hypothesis that there is no association between a set of predictive features and risks for relatives.

Multivariate linear regression models were also used for estimating and testing associations between the measured pathology features and risk for relatives. These models were fitted using Bayesian regularised regression with the Least Absolute Shrinkage and Selection Operator (LASSO) penalty function $[27,28]$. The outcome variable was the difference between expected and observed
SIRs, while the pathology features were used as binary explanatory variables. To estimate the logistic regression parameters, we generated $10^{5}$ samples from the posterior distribution of the parameters given the data, discarded the first $2 \times 10^{4}$ samples as burnin, and accepted every fifth posterior sample, thus reducing autocorrelation within the chain.

Because many of the pathology features were highly correlated, Bayesian LASSO regression and the Cox proportional hazards model were used in tandem to select features to be included in the multivariate model.

Statistical analyses were performed with Stata version 11, StataCorp LP, College Station, Texas, USA [29] and MATLAB ${ }^{\circledR}$ version 7.13, MathWorks, Natick, Massachusetts, USA [30]. All statistical tests were two-sided and $P$-values $<0.05$ were considered nominally statistically significant.

\section{Results}

A total of 856 index cases diagnosed with a first primary invasive breast cancer before the age of 40 years was recruited, of whom 452 had a tumour morphology review using archived tissue. Of these, 77 (17\%) had either a high-risk mutation in a breast cancer susceptibility gene or methylation of the promoter region of $B R C A 1$ in peripheral blood DNA (31 BRCA1, 16 BRCA2, 1 ATM, 4 TP53, $25 B R C A 1$ promoter region methylation). The remaining 375 (83\%) constituted the subgroup for further analyses. Table 1 shows the distribution of each tumour morphology feature for all the 452 index cases and for the 375 index cases in the subgroup. ER and PR status was available for 401 (89\%) of all index cases and for 329 (89\%) of the subgroup of index cases.

There were 1,041 relatives (452 mothers and 589 sisters) of the index cases, an average of 2.3 relatives per index case, with a total of 11,786 person-years of observation (6,340 person-years for mothers and 5,446 personyears for sisters). Data were imputed for relatives with missing data as follows: seven dates of birth; six vital status; four dates and ages at death; and one date and age at breast cancer diagnosis.

Overall, 106 breast cancers were observed for the mothers and sisters of the index cases while 36.56 were expected from population incidence rates. The ratio of observed to expected, the SIR, was 2.90 with a $95 \% \mathrm{CI}$ from 2.40 to 3.51 .

Table 2 shows, for the presence and absence of each of the pathology features, the number of observed and expected cases of breast cancer, the SIR and 95\% CI. Table 2 also shows the ratio of SIRs and corresponding 95\% CI and the $P$-values as a test of the difference between the SIRs for the presence and absence of each pathology feature. The test of the null hypothesis of no 
Table 1 Number and percentage of index cases with each of the tumour morphology features

\begin{tabular}{|c|c|c|c|c|}
\hline \multirow[t]{2}{*}{ Feature } & \multicolumn{2}{|c|}{$\begin{array}{l}\text { All index } \\
\text { cases }\end{array}$} & \multicolumn{2}{|c|}{$\begin{array}{l}\text { Subgroup of index } \\
\text { cases }\end{array}$} \\
\hline & $\mathrm{N}=452^{\dagger}$ & $\%$ & $\mathrm{~N}=375^{\ddagger}$ & $\%$ \\
\hline Number of mitoses $>50$ & 71 & 15.7 & 33 & 8.8 \\
\hline Nuclear grade - malignant & 386 & 85.4 & 316 & 84.3 \\
\hline Tubule formation $<10$ & 344 & 76.1 & 283 & 75.5 \\
\hline Syncytial pattern $\geq 75 \%$ & 36 & 8.0 & 21 & 5.6 \\
\hline Circumscribed & 93 & 20.6 & 56 & 14.9 \\
\hline Pushing margins & 16 & 3.5 & 11 & 2.9 \\
\hline Lymphocytic infiltrate I - diffuse & 162 & 35.8 & 136 & 36.3 \\
\hline Lymphocytic infiltrate II - intense & 96 & 21.2 & 69 & 18.4 \\
\hline Glandular growth pattern & 307 & 67.9 & 272 & 75.5 \\
\hline Lobular growth pattern & 162 & 35.8 & 147 & 39.2 \\
\hline Trabecular growth pattern & 109 & 24.1 & 65 & 17.3 \\
\hline Tubular growth pattern & 74 & 16.4 & 64 & 17.1 \\
\hline Acinar growth pattern & 87 & 19.3 & 60 & 16.0 \\
\hline Sclerosis - extensive & 420 & 92.9 & 356 & 94.9 \\
\hline Extensive intraductal carcinoma & 70 & 15.5 & 63 & 16.8 \\
\hline Necrosis & 173 & 38.3 & 126 & 33.6 \\
\hline Apoptosis - moderate or intense & 362 & 80.1 & 294 & 78.4 \\
\hline Lymphatic invasion & 141 & 31.2 & 117 & 31.2 \\
\hline ER positive & 226 & 56.4 & 201 & 61.1 \\
\hline PR positive & 258 & 64.3 & 219 & 66.6 \\
\hline
\end{tabular}

† ER and PR status was available for 401 index cases.

f ER and PR status was available for 329 index cases.

association with these variables and risks for relatives was rejected $\left(\mathrm{X}_{18}{ }^{2}=106 ; P=10^{-14}\right)$. After fitting the five significant morphology features, there was still significant variation in risks for relatives across the remaining 13 features $\left(\mathrm{X}_{13}^{2}=30 ; P=0.004\right)$.

Breast cancer risks for female first-degree relatives were increased if the index cases' tumours: were circumscribed; had pushing margins $>50 \%$; had intense lymphocytic infiltrate II; had number of mitoses $>50$; had a trabecular growth pattern; had extensive intraductal carcinoma; had a syncytial pattern; did not have extensive sclerosis; did not have a glandular growth pattern; or were ER or PR negative (all $P<0.04$ ).

Table 3 shows the HR, 95\% CI and $P$-values for the multivariate model. When all features were considered together, the risks for relatives could be described by six predictive features: absence of extensive sclerosis; acinar growth pattern; trabecular growth pattern; glandular growth pattern; lobular growth pattern; and extensive intraductal carcinoma (all $P<0.02$ ). When these factors were included in the model, there was at best marginally significant evidence for associations with tubular growth pattern $(\mathrm{HR}=0.51 ; 95 \% \mathrm{CI} 0.28$ to $0.93 ; P=0.03)$ and tubule formation $(\mathrm{HR}=1.64 ; 95 \% \mathrm{CI} 0.97$ to $2.78 ; P=$ 0.07). Neither ER status nor PR status provided additional (i.e. independent) information on breast cancer risk for relatives (both $P>0.3$ ).

\section{Subgroup analyses}

When restricted to the subgroup of 375 index cases, there were 876 relatives ( 375 mothers and 501 sisters), an average of 2.3 relatives per index case, with a total of 9,954 person-years of observation (5,287 person-years for mothers and 4,667 person-years for sisters). Overall, 69 breast cancers were observed and 30.74 were expected based on population incidence rates; the SIR was 2.25 with a $95 \%$ CI from 1.77 to 2.84 .

Table 4 shows SIR and 95\% CI and the ratio of the SIRs for each of the pathology features. Breast cancer risks for relatives were increased if the tumours: were circumscribed; had pushing margins; had extensive intraductal carcinoma; had glandular growth pattern; or did not have extensive sclerosis (all $P<0.04$ ). Neither ER status nor PR status provided independent information on breast cancer risk for relatives (both $P>0.4$ ). The test of the null hypothesis of no association with these variables and risks for relatives was rejected $\left(\mathrm{X}_{18}{ }^{2}=\right.$ 71.0; $P=10^{-8}$ ). Even after fitting the four significant morphology features there was still significant variation in risks for relatives across the remaining 13 features $\left(\mathrm{X}_{14}^{2}=45.4 ; P=0.0001\right)$.

Table 5 shows the HR, 95\% CI and $P$-values for the multivariate model. When all features were considered together, the pathology features identified by the Bayesian LASSO regression and the Cox proportional hazards models were: being circumscribed; having extensive intraductal carcinoma; having lobular growth pattern; and not having extensive sclerosis (all $P<0.02$ ). When these factors were included in the model, no other factors were even marginally associated.

Figure 1 shows that, based on the model presented in Table 5, it would be predicted that women with breast cancer diagnosed before age 40 years who do not have a currently identifiable genetic risk, can be divided into three groups defined by the four pathology features. Relatives of the 128 (34\%) index cases with none of these features are predicted to be at no increased risk $(\mathrm{SIR}=1.03,95 \% \mathrm{CI}=0.57$ to 1.85$)$ while relatives of the $37(10 \%)$ cases who had two or more features were predicted to be at highest risk ( $\mathrm{SIR}=5.18,95 \% \mathrm{CI}=3.22$ to 8.33). The remaining 210 (56\%) cases are predicted to be at about average increased risk $(\mathrm{SIR}=2.45,95 \% \mathrm{CI}=$ 1.80 to 3.33 ).

Figure 2 shows that some of the morphological and immunohistochemical features are strongly associated with one another, for both all index cases and for the subgroup of index cases; cf. Figure 2 of [12]. For example, notice that syncytial pattern and pushing margins 
Table 2 SIRs for mothers and sisters by tumour morphology features of the $\mathbf{4 5 2}$ index cases: the Australian Breast Cancer Family Registry.

\begin{tabular}{|c|c|c|c|c|c|c|c|c|}
\hline Feature & & Observed & Expeceted & SIR & $(95 \% \mathrm{Cl})$ & Ratio of SIRs & $(95 \% \mathrm{Cl})$ & $P$ \\
\hline \multirow[t]{2}{*}{ Number of mitoses $>50$} & Absent & 81 & 31.70 & 2.56 & (2.06 to 3.18$)$ & 2.01 & (1.23 to 3.19$)$ & 0.002 \\
\hline & Present & 25 & 4.86 & 5.14 & (3.47 to 7.61 ) & & & \\
\hline \multirow[t]{2}{*}{ Nuclear grade - malignant } & Absent & 13 & 5.32 & 2.44 & (1.42 to 4.21$)$ & 1.22 & (0.68 to 2.37 ) & 0.5 \\
\hline & Present & 93 & 31.24 & 2.98 & (2.43 to 3.65$)$ & & & \\
\hline \multirow[t]{2}{*}{ Tubule formation $<10$} & Absent & 21 & 9.18 & 2.29 & (1.49 to 3.51$)$ & 1.36 & (0.83 to 2.30$)$ & 0.2 \\
\hline & Present & 85 & 27.38 & 3.10 & (2.51 to 3.84 ) & & & \\
\hline \multirow[t]{2}{*}{ Syncytial pattern $\geq 75 \%$} & Absent & 92 & 34.20 & 2.69 & (2.19 to 3.30$)$ & 2.21 & (1.16 to 3.89$)$ & 0.01 \\
\hline & Present & 14 & 2.36 & 5.93 & (3.51 to 10.01 ) & & & \\
\hline \multirow[t]{2}{*}{ Circumscribed } & Absent & 70 & 29.51 & 2.37 & (1.88 to 3.00$)$ & 2.15 & (1.40 to 3.26$)$ & $<0.001$ \\
\hline & Present & 36 & 7.05 & 5.11 & (3.68 to 7.08 ) & & & \\
\hline \multirow[t]{2}{*}{ Pushing margins } & Absent & 96 & 35.40 & 2.71 & (2.22 to 3.31$)$ & 3.15 & (1.46 to 6.05$)$ & 0.001 \\
\hline & Present & 10 & 1.17 & 8.58 & (4.62 to 15.95$)$ & & & \\
\hline \multirow[t]{2}{*}{ Lymphocytic infiltrate I - diffuse } & Absent & 58 & 23.20 & 2.50 & (1.93 to 3.23$)$ & 1.44 & (0.96 to 2.14$)$ & 0.06 \\
\hline & Present & 48 & 13.36 & 3.59 & (2.71 to 4.77$)$ & & & \\
\hline \multirow[t]{2}{*}{ Lymphocytic infiltrate II-intense } & Absent & 73 & 29.83 & 2.45 & (1.95 to 3.08$)$ & 2.00 & (1.29 to 3.06$)$ & 0.001 \\
\hline & Present & 33 & 6.73 & 4.90 & (3.49 to 6.90$)$ & & & \\
\hline \multirow{2}{*}{ Glandular growth pattern } & Absent & 47 & 10.80 & 4.35 & (3.27 to 5.79 ) & 0.53 & (0.35 to 0.79$)$ & 0.001 \\
\hline & Present & 59 & 25.76 & 2.29 & (1.77 to 2.96$)$ & & & \\
\hline \multirow[t]{2}{*}{ Lobular growth pattern } & Absent & 62 & 22.80 & 2.72 & (2.12 to 4.89 ) & 1.18 & (0.78 to 1.76$)$ & 0.4 \\
\hline & Present & 44 & 13.76 & 3.20 & (2.38 to 4.30$)$ & & & \\
\hline \multirow[t]{2}{*}{ Trabecular growth pattern } & Absent & 70 & 28.65 & 2.44 & (1.93 to 3.09$)$ & 1.86 & (1.21 to 2.82$)$ & 0.002 \\
\hline & Present & 36 & 7.91 & 4.55 & (3.28 to 6.31 ) & & & \\
\hline \multirow[t]{2}{*}{ Tubular growth pattern } & Absent & 91 & 30.34 & 3.00 & (2.44 to 3.68$)$ & 0.80 & (0.43 to 1.39$)$ & 0.4 \\
\hline & Present & 15 & 6.23 & 2.41 & (1.45 to 4.00$)$ & & & \\
\hline \multirow[t]{2}{*}{ Acinar growth pattern } & Absent & 90 & 30.03 & 3.00 & (2.44 to 3.68$)$ & 0.82 & (0.45 to 1.40$)$ & 0.5 \\
\hline & Present & 16 & 6.53 & 2.45 & (1.51 to 4.00$)$ & & & \\
\hline \multirow[t]{2}{*}{ Sclerosis - extensive } & Absent & 20 & 2.36 & 8.46 & (5.46 to 13.11$)$ & 0.30 & (0.18 to 0.51$)$ & $<0.001$ \\
\hline & Present & 86 & 34.20 & 2.52 & (2.04 to 3.11$)$ & & & \\
\hline \multirow[t]{2}{*}{ Extensive intraductal carcinoma } & Absent & 81 & 30.74 & 2.34 & (2.12 to 3.28$)$ & 1.63 & (1.00 to 2.58$)$ & 0.03 \\
\hline & Present & 25 & 5.82 & 4.30 & (2.90 to 6.36$)$ & & & \\
\hline \multirow[t]{2}{*}{ Necrosis } & Absent & 64 & 23.93 & 2.67 & (2.09 to 3.42 ) & 1.24 & (0.82 to 1.86$)$ & 0.3 \\
\hline & Present & 42 & 13.63 & 3.33 & (2.46 to 4.50$)$ & & & \\
\hline \multirow[t]{2}{*}{ Apoptosis - moderate or intense } & Absent & 16 & 7.30 & 2.19 & (1.34 to 3.58$)$ & 1.40 & (0.82 to 1.86$)$ & 0.2 \\
\hline & Present & 90 & 29.26 & 3.08 & (2.50 to 3.78$)$ & & & \\
\hline \multirow[t]{2}{*}{ Lymphatic invasion } & Absent & 75 & 24.96 & 3.01 & (2.40 to 3.77 ) & 0.89 & (0.57 to 1.37$)$ & 0.6 \\
\hline & Present & 31 & 11.60 & 2.67 & (1.88 to 3.80$)$ & & & \\
\hline \multirow[t]{2}{*}{ ER positive } & Absent & 48 & 13.16 & 3.65 & (2.75 to 4.84 ) & 0.63 & (0.41 to 0.96 ) & 0.02 \\
\hline & Present & 46 & 20.16 & 2.28 & (1.71 to 3.05 ) & & & \\
\hline \multirow[t]{2}{*}{ PR positive } & Absent & 42 & 11.32 & 3.71 & (2.75 to 5.02 ) & 0.66 & (0.43 to 1.01 ) & 0.04 \\
\hline & Present & 54 & 22.03 & 2.45 & (1.88 to 3.20$)$ & & & \\
\hline
\end{tabular}

Table 3 Multivariate modelling of hazard ratios for tumour morphology features of the index cases.

\begin{tabular}{llll}
\hline Feature & Hazard Ratio & $\mathbf{( 9 5 \% ~ C l )}$ & $\boldsymbol{P}$ \\
\hline Sclerosis - extensive & 0.36 & $(0.20$ to 0.65$)$ & 0.001 \\
Acinar growth pattern & 0.42 & $(0.22$ to 0.78$)$ & 0.006 \\
Glandular growth pattern & 0.40 & $(0.25$ to 0.65$)$ & $<0.001$ \\
Extensive intraductal carcinoma & 1.96 & $(1.28$ to 3.00$)$ & 0.002 \\
Circumscribed & 1.85 & $(1.10$ to 3.12$)$ & 0.02 \\
\hline
\end{tabular}

are highly associated with each other and several other features for both groups.

\section{Discussion}

For women with early-onset breast cancer who neither carry a mutation in a known breast cancer susceptibility gene nor have $B R C A 1$ promoter region methylation in peripheral blood DNA, features of their tumour morphology predict wide variation in the risk of breast 
Table 4 SIRs for mothers and sisters by morphology features of the subgroup of $\mathbf{3 7 5}$ index cases.

\begin{tabular}{|c|c|c|c|c|c|c|c|c|}
\hline Feature & & Observed & Expeceted & SIR & $(95 \% \mathrm{Cl})$ & Ratio of SIRs & $(95 \% \mathrm{Cl})$ & $P$ \\
\hline \multirow[t]{2}{*}{ Number of mitoses $>50$} & Absent & 60 & 28.50 & 2.11 & (1.64 to 2.71$)$ & 1.91 & (0.83 to 3.87 ) & 0.07 \\
\hline & Present & 9 & 2.24 & 4.02 & (2.09 to 7.73 ) & & & \\
\hline \multirow[t]{2}{*}{ Nuclear grade - malignant } & Absent & 10 & 4.67 & 2.14 & (1.15 to 3.98$)$ & 1.06 & (0.54 to 2.32$)$ & 0.9 \\
\hline & Present & 59 & 26.06 & 2.26 & (1.75 to 2.92$)$ & & & \\
\hline \multirow[t]{2}{*}{ Tubule formation $<10$} & Absent & 16 & 7.86 & 2.04 & (1.25 to 3.32$)$ & 1.14 & (0.64 to 2.13 ) & 0.7 \\
\hline & Present & 53 & 22.87 & 2.32 & (1.77 to 3.03$)$ & & & \\
\hline \multirow[t]{2}{*}{ Syncytial pattern $\geq 75 \%$} & Absent & 64 & 29.42 & 2.18 & (1.70 to 2.78$)$ & 1.75 & (0.55 to 4.31$)$ & 0.2 \\
\hline & Present & 5 & 1.31 & 3.81 & (1.58 to 9.14$)$ & & & \\
\hline \multirow[t]{2}{*}{ Circumscribed } & Absent & 51 & 26.29 & 1.94 & (1.47 to 2.55$)$ & 2.09 & (1.15 to 3.63$)$ & 0.01 \\
\hline & Present & 18 & 4.45 & 4.04 & (2.55 to 6.42$)$ & & & \\
\hline \multirow[t]{2}{*}{ Pushing margins } & Absent & 66 & 29.98 & 2.10 & (1.64 to 2.69$)$ & 3.76 & (1.33 to 8.64$)$ & 0.002 \\
\hline & Present & 6 & 0.76 & 7.90 & (3.55 to 17.59$)$ & & & \\
\hline \multirow[t]{2}{*}{ Lymphocytic infiltrate I - diffuse } & Absent & 38 & 19.42 & 1.96 & (1.42 to 2.69$)$ & 1.40 & (0.84 to 2.31$)$ & 0.2 \\
\hline & Present & 31 & 11.32 & 2.74 & (1.93 to 3.89$)$ & & & \\
\hline \multirow[t]{2}{*}{ Lymphocytic infiltrate II-intense } & Absent & 53 & 25.89 & 2.05 & (1.56 to 2.68$)$ & 1.61 & (0.86 to 2.86$)$ & 0.1 \\
\hline & Present & 16 & 4.85 & 3.30 & (2.02 to 5.39$)$ & & & \\
\hline \multirow[t]{2}{*}{ Glandular growth pattern } & Absent & 25 & 7.58 & 3.30 & (2.23 to 4.88$)$ & 0.58 & (0.34 to 0.98$)$ & 0.03 \\
\hline & Present & 44 & 23.16 & 1.90 & (1.41 to 2.55$)$ & & & \\
\hline \multirow[t]{2}{*}{ Lobular growth pattern } & Absent & 36 & 18.34 & 1.96 & (1.42 to 2.72$)$ & 1.36 & (0.82 to 2.24$)$ & 0.2 \\
\hline & Present & 33 & 12.40 & 2.66 & (1.89 to 3.74$)$ & & & \\
\hline \multirow[t]{2}{*}{ Trabecular growth pattern } & Absent & 54 & 25.90 & 2.09 & (1.60 to 2.72$)$ & 1.49 & (0.78 to 2.67$)$ & 0.2 \\
\hline & Present & 15 & 4.84 & 3.10 & (1.87 to 5.15$)$ & & & \\
\hline \multirow[t]{2}{*}{ Tubular growth pattern } & Absent & 59 & 25.25 & 2.34 & (1.81 to 3.02$)$ & 0.78 & (0.36 to 1.54$)$ & 0.5 \\
\hline & Present & 10 & 5.49 & 1.82 & (0.98 to 3.39$)$ & & & \\
\hline \multirow[t]{2}{*}{ Acinar growth pattern } & Absent & 62 & 26.10 & 2.37 & (1.85 to 3.04$)$ & 0.65 & (0.25 to 1.42$)$ & 0.3 \\
\hline & Present & 7 & 4.56 & 1.54 & (0.73 to 3.22$)$ & & & \\
\hline \multirow[t]{2}{*}{ Sclerosis - extensive } & Absent & 8 & 1.45 & 5.52 & (2.76 to 11.04$)$ & 0.38 & (0.18 to 0.91$)$ & 0.01 \\
\hline & Present & 61 & 29.29 & 2.08 & (1.62 to 2.68$)$ & & & \\
\hline \multirow[t]{2}{*}{ Extensive intraductal carcinoma } & Absent & 51 & 25.61 & 1.99 & (1.51 to 2.62$)$ & 1.77 & (0.97 to 3.06$)$ & 0.04 \\
\hline & Present & 18 & 5.12 & 3.51 & (2.21 to 5.58$)$ & & & \\
\hline \multirow[t]{2}{*}{ Necrosis } & Absent & 48 & 21.35 & 2.25 & (1.70 to 2.98$)$ & 0.99 & (0.57 to 1.69$)$ & 1.0 \\
\hline & Present & 21 & 9.39 & 2.24 & (1.46 to 3.43$)$ & & & \\
\hline \multirow[t]{2}{*}{ Apoptosis - moderate or intense } & Absent & 12 & 6.64 & 1.81 & (1.03 to 3.18$)$ & 1.31 & (0.69 to 2.68$)$ & 0.4 \\
\hline & Present & 57 & 24.10 & 2.37 & (1.83 to 3.07$)$ & & & \\
\hline \multirow[t]{2}{*}{ Lymphatic invasion } & Absent & 53 & 21.10 & 2.51 & (1.92 to 3.29$)$ & 0.76 & (0.35 to 1.17$)$ & 0.1 \\
\hline & Present & 16 & 9.64 & 1.66 & (1.02 to 2.71$)$ & & & \\
\hline \multirow[t]{2}{*}{ ER positive } & Absent & 25 & 10.00 & 2.50 & (1.69 to 3.70 ) & 0.65 & (0.44 to 1.33 ) & 0.3 \\
\hline & Present & 34 & 17.85 & 1.91 & (1.36 to 2.67 ) & & & \\
\hline \multirow[t]{2}{*}{ PR positive } & Absent & 26 & 9.10 & 2.86 & (1.95 to 4.20$)$ & 0.70 & (0.38 to 1.13 ) & 0.1 \\
\hline & Present & 35 & 18.78 & 1.86 & (1.34 to 2.60$)$ & & & \\
\hline
\end{tabular}

Table 5 Multivariate modelling of hazard ratios for morphology features of the subgroup of $\mathbf{3 7 5}$ index cases.

\begin{tabular}{llll}
\hline Feature & Hazard Ratio & $\mathbf{( 9 5 \% ~ C l )}$ & $\boldsymbol{P}$ \\
\hline Sclerosis-extensive & 0.30 & $(0.13$ to 0.70$)$ & 0.005 \\
Circumscribed & 2.91 & $(1.39$ to 6.10$)$ & 0.01 \\
Extensive intraductal carcinoma & 2.21 & $(1.25$ to 3.90$)$ & 0.01 \\
Lobular growth pattern & 2.01 & $(1.10$ to 3.70$)$ & 0.02 \\
\hline
\end{tabular}

cancer for their first-degree female relatives, far more than could be attributed to chance. For example, female relatives of the approximately one-third of early-onset breast cancer cases who had tumours that lacked any morphological feature associated with familial risk were at no increased risk of breast cancer. Female relatives of the approximately one-sixth of early-onset breast cancer 


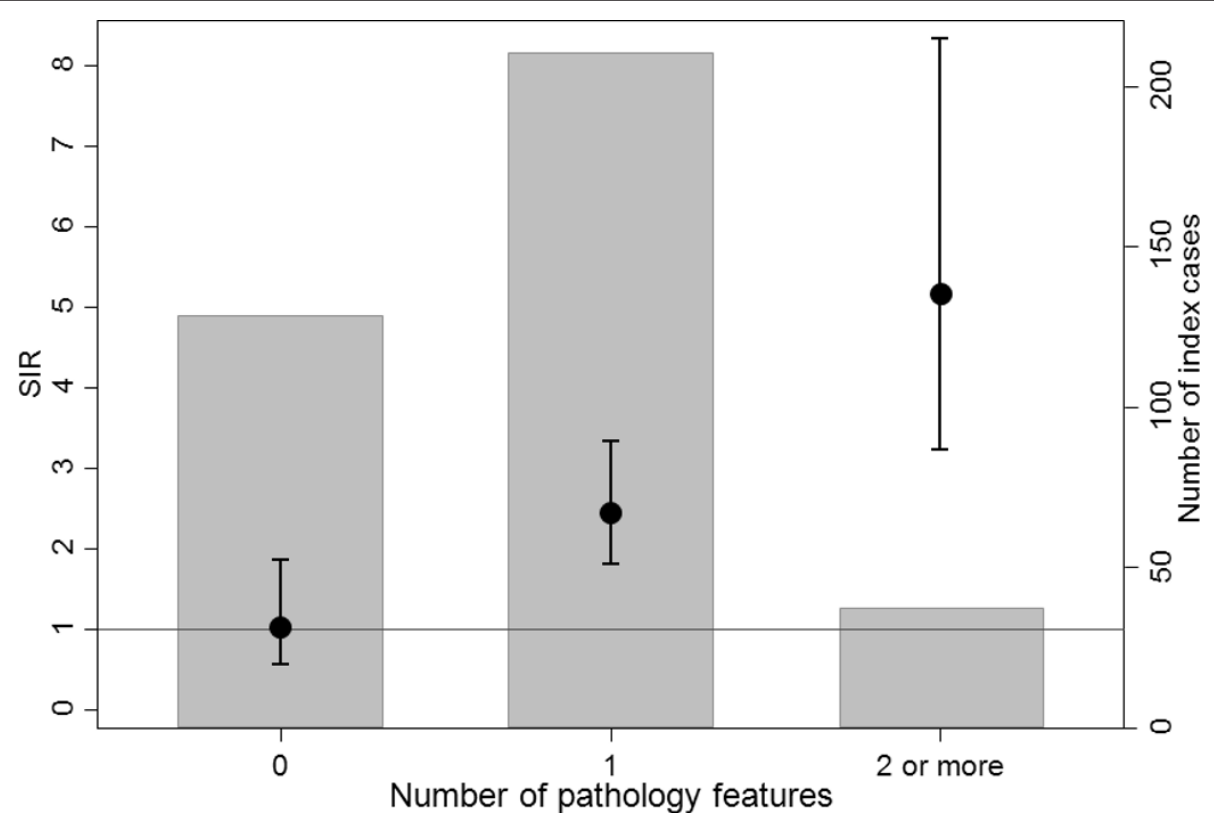

Figure 1 SIRs (95\% Cls) for mothers and sisters of 375 index cases by number of pathology features. Grey areas represent the proportion of index cases with given number of features.

cases who had tumours that had two or more of the four features associated with familial risk were at a substantially increased risk of breast cancer. The latter finding suggests there are undiscovered strong familial risk factors for early-onset breast cancer. The former suggests there is a substantial proportion of early-onset breast cancer that does not have a familial, let alone genetic, cause.

This work has built on previous work by us and others that identified specific morphological features

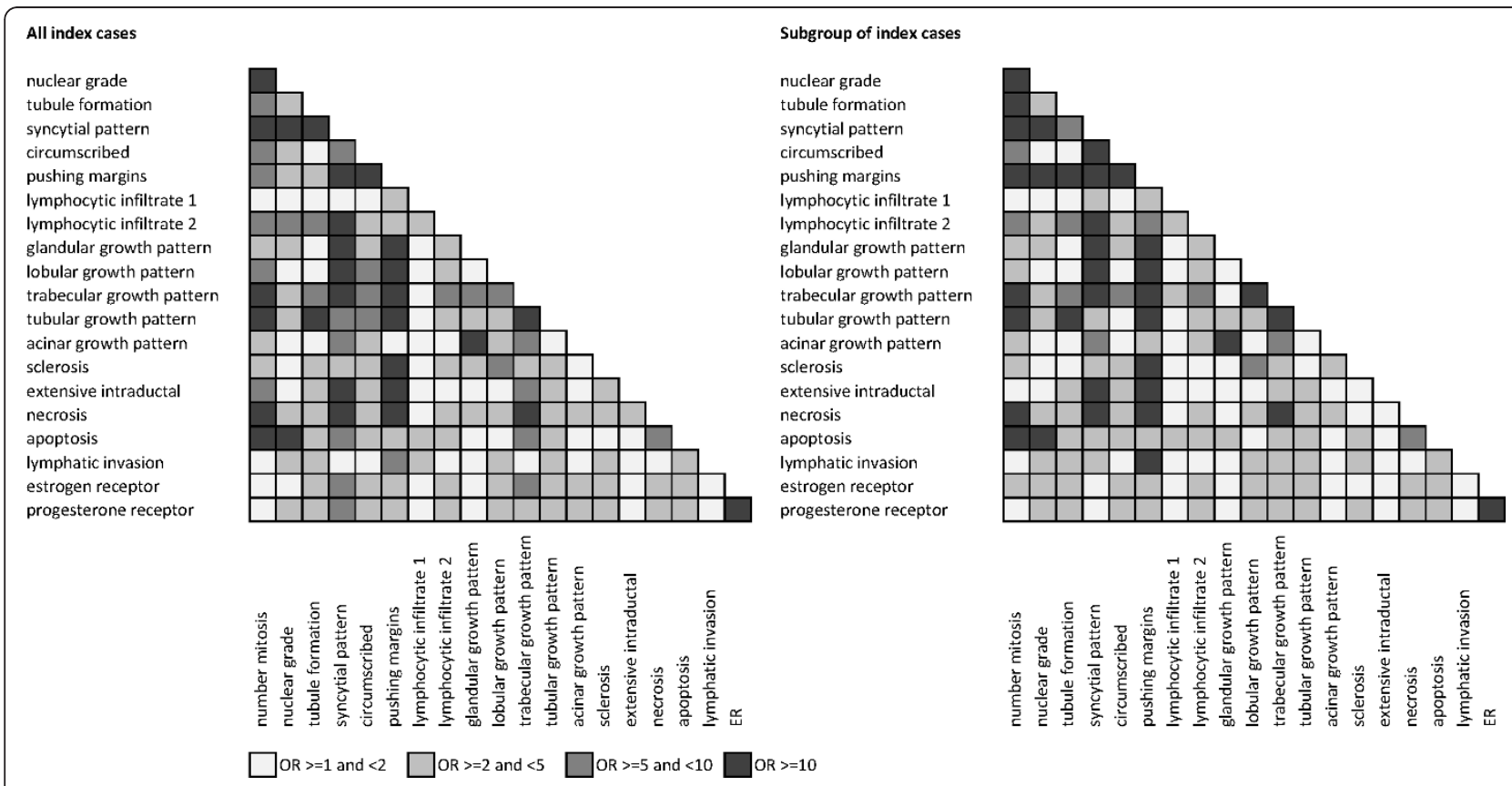

Figure 2 Associations between pathology features for all index cases (left) and the subgroup of cases (right). Each row and column corresponds to a feature and the shading represents different levels of association, as measured by the odds ratios (ORs), as indicated. Odds ratios $<1$ were assigned the same levels as their reciprocals. 
which predict cases with a germline $B R C A 1$ mutation $[12,31,32]$. We recently extended this to show that those features also predict cases with methylation of the promoter region of BRCA1 in peripheral blood DNA [13]. Here, we have widened the scope of what we are predicting to risks for relatives and, at the same time, included all the other morphological features assessed by a standardised and validated pathology review [18]. We also assessed morphological predictors both including and excluding cases with a known genetic cause or methylation of the BRCA1 promoter region.

When first considering all index cases, we found that absence of extensive sclerosis, extensive intraductal carcinoma, and trabecular and lobular growth patterns and absence of acinar and glandular growth patterns were all independent predictors of breast cancer for their firstdegree female relatives. When considered together, for each of these six features their presence was associated with an approximate doubling of risk for relatives. This means there is a substantial gradient of risk for relatives across a number of these features.

We have previously shown that the presence of trabecular growth pattern was the major predictor of $B R C A 1$ mutation status, as well as of methylation of the BRCA1 promoter region $[12,13]$. When we excluded index cases with known genetic causes or methylation of the BRCA1 promoter region, absence of extensive sclerosis, circumscribed growth, extensive intraductal carcinoma and lobular growth pattern were each independent predictors of breast cancer risk for the first-degree female relatives of the remaining index cases. Note from Figure 2 that these factors are not highly associated with one another. Again, the strengths of prediction were each an approximate doubling or more of risk, and there was a substantial gradient in risk for the relatives associated with the number of these four features in the tumour of the index case. Therefore, this study has identified characteristics of breast cancers in young women, other than basal-like carcinoma (which is likely rare in our subgroup analyses due to exclusion of the index cases with either known $B R C A 1$ germline mutations or methylation of the BRCA1 promoter region), that are associated with increased risks of breast cancer for first-degree relatives.

There are several strengths of our study. First, it is population-based, so inference can readily be made at least to the populations from which these index cases were sampled, if not more generally. Second, because the index cases were not selected on the basis of family history, this study gives insights across the whole spectrum of index cases. Third, we have used data from multiple pathologists conducting a standardised and validated tumour review and any systematic variation across the pathologists would mean that our study has under-estimated the predictive value of these morphology features.
The study also has some weaknesses. It is possible that, despite extensive testing, some index cases carrying mutations in BRCA1 and BRCA2 have not yet been identified, although this is likely to be, at most, a few percent $[3,6]$. There may be some false positive statistical results due to the vagaries of chance. The study has used only early-onset index cases, so we cannot infer that the same results will apply to index cases of later onset. Our index cases were predominantly Caucasian and we cannot infer that these results apply to other populations. Therefore, there is a need for replication using independent samples, and using samples of index cases with different ages at onset and different ethnic backgrounds. Finally, although we have identified a small number of features that independently predict risks for relatives in our data set, there was still substantial unexplained variation in risk. Therefore, larger and pooled studies might identify a bigger and better set of predictors. These might also clarify which factors are the better independent predictors, given that some features are highly associated with one another (see Figure 2).

While there are several studies of breast cancer in relatives as a function of the ER and PR tumour status of an affected woman (for example, [33]), few have studied histological features (for example, [34]). Several studies have shown that stratification of breast tumours by ER and PR status might be useful in partitioning breast cancer families into more homogeneous subsets [35], but we have found that these traditional immunohistochemical features are not as important as morphological features for predicting BRCA1 mutation carriers [12] or, as in this study, predicting breast cancer risks for relatives. Specific morphological types of breast cancer might be associated with familial cancers in general (or example, [36]).

Being able to quantify a woman's risk of breast cancer is important for genetic counselling, prevention and screening, as well as for aetiological research. Currently, risk estimates associated with having a family history are based on the age at diagnosis of cancer, not on the cancer's morphological features. We have shown here that, at least for first-degree relatives of women with early-onset breast cancer, this is likely leading to a misassignment of familial risks for about one-half of index cases, being too high for one-third and too low for one-sixth, by factors of two-fold or more. Assignment of women with a family history of breast cancer to different screening strategies based on their absolute risk could be substantially improved were the morphology features of the tumours of the relatives taken into account. The role of morphological features to predict BRAC1 mutation status has been established for some time [31]. For early-onset breast cancer, we showed that only two key features could better predict $B R C A 1$ mutation carriers than family history and/or ER and PR tumour status [12]. Now we have shown that just four 
other morphological features predict familial risks after excluding the known breast susceptibility genes, and again better than ER and PR tumour status.

It is highly relevant to genetic research and counselling that one-third of early-onset breast cancers might not even have a heritable genetic basis, as evidenced by our observation that, for the group of index cases with none of the four predictive features, their relatives were not at increased risk. Most linkage studies and the recent genome-wide association studies have generally pooled all cases when trying to find predisposing genes. It is also of relevance to know if the type of breast cancers, as defined by the morphology features identified here, 'runs in the family', as this would greatly assist efforts at susceptibility gene discovery.

For the affected women, their germline status, as well as changes (both somatic genetic and epigenetic) to tumour DNA, might influence gene expression that manifests in nuances of cell growth and neoplastic tissue organisation that are able to be observed by microscope. For example, breast tumours arising in women with germline BRCA1 mutations and TP53 mutations have characteristic morphology and acquired genetic and epigenetic mutation profiles [37-39]. For unaffected relatives, any familial risk associated with the breast tumour morphology features of an affected relative must be related to similar genetic or epigenetic variants that increase cancer susceptibility. From this, it follows that DNA from affected women whose breast tumour morphology features are associated with the highest familial risks should be prioritised for comprehensive genetic and epigenetic screening as they provide the best prospect for the discovery of novel variants that are associated with risk.

On their own, the ER and PR status of the index cases were both associated with risk for relatives overall, with about a $50 \%$ increased risk if the tumour of the index case was negative for either of these immunohistochemical markers. After the exclusions, the associations were of the same magnitude and direction but no longer statistically significant. However, neither of these immunohistochemical markers were independent predictors of risks for relatives once the more strongly predictive morphological features were taken into account. That is, we present here an advance on using ER and PR alone to assess the role of pathology in predicting increased familial and possibly genetic risks.

\section{Conclusions}

We have shown that relatively standard tumour morphology can help unravel the complex heterogeneity of breast cancers from the perspective of familial and genetic risk, at least in the setting of early-onset disease. There is a very wide variation in risks for relatives based on tumour characteristics and this could not only be of clinical value but might help discover new breast cancer susceptibility genes.

\section{Abbreviations}

ABCFR: Australian Breast Cancer Family Registry; Cl: confidence interval; ER: estrogen receptor; HR: hazard ratio; LASSO: least absolute shrinkage and selection operator; PR: progesterone receptor; SIR: standardised incidence ratio

\section{Acknowledgements}

We would like to thank the study pathologists Dr Jane Armes, Dr Deon Venter, Dr Elena Provenzano, Dr Sarbar Napaki and Dr Beena Kumar who reviewed archival tumour materials for the Australian Breast Cancer Family Registry (ABCFR). We wish to thank Margaret McCredie for her key role in the establishment and leadership of the ABCFR in Sydney, Australia. The ABCFR has been supported in Australia by the National Health and Medical Research Council, the New South Wales Cancer Council, the Victorian Health Promotion Foundation, the Victorian Breast Cancer Research Consortium, Cancer Australia and the National Breast Cancer Foundation. The ABCFR has also been supported by the National Cancer Institute, National Institutes of Health, USA under RFA CA-06-503 and through cooperative agreements with members of the Breast Cancer Family Registry: The University of Melbourne, Melbourne, Victoria, Australia (U01 CA69638), Fox Chase Cancer Center, Philadelphia, Pennsylvania, USA (U01 CA69631), Huntsman Cancer Institute, Salt Lake City, Utah, USA (U01 CA69446), Columbia University, New York, New York, USA (U01 CA69398), Cancer Prevention Institute of California, Fremont, California, USA (U01 CA69417), and Cancer Care Ontario, Toronto, Ontario, Canada (U01 CA69467). The content of this article does not necessarily reflect the views or policies of the National Cancer Institute or any of the collaborating centres of the Breast CFR. The mention of trade names, commercial products or organisations does not imply endorsement by the US government or the Breast Cancer Family Registry.

Prof John Hopper is an Australia Fellow of the National Health and Medical Research Council and Prof Melissa Southey is a Senior Research Fellow of the National Health and Medical Research Council. Both Prof John Hopper and Prof Melissa Southey are group leaders of the Victorian Breast Cancer Research Consortium.

\section{Author details}

${ }^{1}$ Centre for Molecular, Environmental, Genetic and Analytic Epidemiology, The University of Melbourne, Melbourne, VIC, Australia. ${ }^{2}$ Cancer Epidemiology Centre, Cancer Council Victoria, Carlton, VIC, Australia. ${ }^{3}$ Department of Pathology, The University of Melbourne, Melbourne, VIC, Australia.

\section{Authors' contributions}

GSD led the writing of the manuscript, reviewed the literature, analysed and interpreted data, and also contributed to the study design and data collection. MCS established the ABCFR and its data collection, conceived the study, contributed to the collection of the data (was responsible for the collection of the pathology review data) and contributed to the data analysis and writing of the manuscript. JLH established the ABCFR and its data collection, conceived the study design, data analysis and interpretation and the writing of the manuscript. EM and DFS conducted the LASSO statistical analyses and contributed to the writing of the manuscript. GGG helped establish the ABCFR and its data collection and contributed to the writing of the manuscript. All authors read and approved the final manuscript.

\section{Competing interests}

The authors declare that they have no competing interests.

Received: 28 March 2012 Revised: 24 August 2012

Accepted: 28 August 2012 Published: 28 August 2012

\section{References}

1. Pharoah PD, Day NE, Duffy S, Easton DF, Ponder BA: Family history and the risk of breast cancer: a systematic review and meta-analysis. Int $J$ Cancer 1997, 71:800-809. 
2. Collaborative Group on Hormonal Factors in Breast Cancer: Familial breast cancer: collaborative reanalysis of individual data from 52 epidemiological studies including 58,209 women with breast cancer and 101,986 women without the disease. Lancet 2001, 358:1389-1399.

3. Dite GS, Jenkins MA, Southey MC, Hocking JS, Giles GG, McCredie MR, Venter DJ, Hopper JL: Familial risks, early-onset breast cancer, and BRCA1 and BRCA2 germline mutations. J Natl Cancer Inst 2003, 95:448-457.

4. Loman N, Bladström A, Johannsson O, Borg A, Olsson H: Cancer incidence in relatives of a population-based set of cases of early-onset breast cancer with a known BRCA1 and BRCA2 mutation status. Breast Cancer Res 2003, 5:R175-R186.

5. Lee JS, John EM, McGuire V, Felberg A, Ostrow KL, DiCioccio RA, Li FP, Miron A, West DW, Whittemore AS: Breast and ovarian cancer in relatives of cancer patients, with and without BRCA mutations. Cancer Epidemiol Biomarkers Prev 2006, 15:359-363.

6. Dite GS, Whittemore AS, Knight JA, John EM, Milne RL, Andrulis IL, Southey MC, McCredie MR, Giles GG, Miron A, Phipps Al, West DW, Hopper JL: Increased cancer risks for relatives of very early-onset breast cancer cases with and without $B R C A 1$ and $B R C A 2$ mutations. $B r J$ Cancer 2010, 103:1103-1108

7. Swift M, Reitnauer PJ, Morrell D, Chase CL: Breast and other cancers in families with ataxia-telangiectasia. N Engl J Med 1987, 316:1289-1294.

8. Li FP, Fraumeni JF Jr: Soft-tissue sarcomas, breast cancer, and other neoplasms. A familial syndrome? Ann Intern Med 1969, 71:747-752.

9. Lalloo F, Varley J, Moran A, Ellis D, O'Dair L, Pharoah P, Antoniou A, Hartley R, Shenton A, Seal S, Bulman B, Howell A, Evans DG: BRCA1, BRCA2 and TP53 mutations in very early-onset breast cancer with associated risks to relatives. Eur I Cancer 2006, 42:1143-1150.

10. Mouchawar J, Korch C, Byers T, Pitts TM, Li E, McCredie MR, Giles GG, Hopper JL, Southey MC: Population-based estimate of the contribution of TP53 mutations to subgroups of early-onset breast cancer: Australian Breast Cancer Family Study. Cancer Res 2010, 70:4795-4800.

11. Turnbull C, Ahmed S, Morrison J, Pernet D, Renwick A, Maranian M, Seal S, Ghoussaini M, Hines S, Healey CS, Hughes D, Warren-Perry M, Tapper W, Eccles D, Evans DG, Breast Cancer Susceptibility Collaboration (UK), Hooning M, Schutte M, van den Ouweland A, Houlston R, Ross G, Langford C, Pharoah PD, Stratton MR, Dunning AM, Rahman N, Easton DF: Genome-wide association study identifies five new breast cancer susceptibility loci. Nat Genet 2010, 42:504-507.

12. Southey MC, Ramus SJ, Dowty JG, Smith LD, Tesoriero AA, Wong EE, Dite GS, Jenkins MA, Byrnes GB, Winship I, Phillips KA, Giles GG, Hopper JL: Morphological predictors of BRCA1 germline mutations in young women with breast cancer. Br J Cancer 2011, 104:903-909.

13. Wong EM, Southey MC, Fox SB, Brown MA, Dowty JG, Jenkins MA, Giles GG, Hopper JL, Dobrovic A: Constitutional methylation of the BRCA1 promoter is specifically associated with BRCA1 mutation-associated pathology in early-onset breast cancer. Cancer Prev Res 2011, 4:23-33.

14. Hopper JL, Giles GG, McCredie MRE, Boyle P: Background, rationale and protocol for a case-control-family study of breast cancer. Breast 1994 3:79-86.

15. McCredie MRE, Dite GS, Giles GG, Hopper JL: Breast cancer in Australian women under the age of 40. Cancer Causes Control 1998, 9:189-198.

16. Hopper JL, Chenevix-Trench G, Jolley D, Dite GS, Jenkins MA, Venter DJ, McCredie MR, Giles GG: Design and analysis issues in a population-based, case-control-family study of the genetic epidemiology of breast cancer and the Co-operative Family Registry for Breast Cancer Studies (CFRBCS). J Natl Cancer Inst Monogr 1999, 26:95-100.

17. Armes JE, Egan AJ, Southey MC, Dite GS, McCredie MR, Giles GG, Hopper JL, Venter DJ: The histologic phenotypes of breast carcinoma occurring before age 40 years in women with and without BRCA1 or BRCA2 germline mutations: a population-based study. Cancer 1998, 83:2335-2345.

18. Longacre TA, Ennis M, Quenneville LA, Bane AL, Bleiweiss IJ, Carter BA Catelano E, Hendrickson MR, Hibshoosh H, Layfield L, Memeo L, Wu H, O'Malley FP: Interobserver agreement and reproducibility in classification of invasive breast carcinoma: an $\mathrm{NCl}$ breast cancer family registry study. Mod Pathol 2006, 19:195-207.

19. Page DL, Anderson TJ, Sakamoto G: Infiltrating carcinoma: major histological types. In Diagnostic Histopathology of the Breast. Edited by: Page DL, Anderson TJ. Edinburgh: Churchill Livingstone; 1987:193-235.
20. Armes JE, Trute L, White D, Southey MC, Hammet F, Tesoriero A, Hutchins AM, Dite GS, McCredie MR, Giles GG, Hopper JL, Venter DJ: Distinct molecular pathogenesis of early-onset breast cancers in $B R C A 1$ and BRCA2 mutation carriers: a population-based study. Cancer Res 1999, 59:2011-2017.

21. McCredie MRE, Dite GS, Southey MC, Venter DJ, Giles GG, Hopper JL: Risk factors for breast cancer by oestrogen receptor and progesterone receptor status. Br J Cancer 2003, 89:1661-1663.

22. Tavtigian SV, Oefner PJ, Babikyan D, Hartmann A, Healey S, Le CalvezKelm F, Lesueur F, Byrnes GB, Chuang SC, Forey N, Feuchtinger C, Gioia L, Hall J, Hashibe M, Herte B, McKay-Chopin S, Thomas A, Vallée MP, Voegele C, Webb PM, Whiteman DC, Australian Cancer Study; Breast Cancer Family Registries (BCFR); Kathleen Cuningham Foundation Consortium for Research into Familial Aspects of Breast Cancer (kConFab), Sangrajrang S, Hopper JL, Southey MC, Andrulis IL, John EM, Chenevix-Trench G: Rare, evolutionarily unlikely missense substitutions in ATM confer increased risk of breast cancer. Am J Hum Genet 2009, 85:427-446.

23. Goldgar DE, Healey S, Dowty JG, Da Silva L, Chen X, Spurdle AB, Terry MB, Daly MJ, Buys SM, Southey MC, Andrulis I, John EM, BCFR; KConFab, Khanna KK, Hopper JL, Oefner PJ, Lakhani S, Chenevix-Trench G: Rare variants in the ATM gene and risk of breast cancer. Breast Cancer Res 2011, 13:R73.

24. Chenevix-Trench G, Spurdle AB, Gatei M, Kelly H, Marsh A, Chen X, Donn K, Cummings M, Nyholt D, Jenkins MA, Scott C, Pupo GM, Dörk T, Bendix R, Kirk J, Tucker K, McCredie MR, Hopper JL, Sambrook J, Mann GJ, Khanna KK: Dominant negative ATM mutations in breast cancer families. J Natl Cancer Inst 2002, 94:205-215, Erratum in. J Natl Cancer Inst, 2002, 94:952.

25. Bernstein JL, Teraoka S, Southey MC, Jenkins MA, Andrulis IL, Knight JA, John EM, Lapinski R, Wolitzer AL, Whittemore AS, West D, Seminara D, Olson ER, Spurdle AB, Chenevix-Trench G, Giles GG, Hopper JL, Concannon P: Population-based estimates of breast cancer risks associated with ATM gene variants c.7271T>G and c.1066-6T>G (IVS10$6 \mathrm{~T}>\mathrm{G})$ from the Breast Cancer Family Registry. Hum Mutat 2006, 27:1122-1128.

26. Breslow NE, Day NE: Statistical Methods in Cancer Research. Volume II - The Design and Analysis of Cohort Studies Lyon, France: International Agency for Research on Cancer; 1987.

27. Park T, Casella G: The Bayesian lasso. J Amer Statistical Assoc 2008, 103:681-686.

28. Kyung M, Gill J, Ghosh M, Casella G: Penalized regression, standard errors, and Bayesian lassos. Bayesian Analysis 2010, 5:369-412.

29. StataCorp: Stata Statistical Software: Release 11.0 College Station, TX: StataCorp LP; 2010.

30. The MathWorks, Inc.: MATLAB version 7.13.0 Natick, Massachusetts: The MathWorks Inc; 2011

31. Lakhani SR, Jacquemier J, Sloane JP, Gusterson BA, Anderson TJ, van de Vijver MJ, Farid LM, Venter D, Antoniou A, Storfer-Isser A, Smyth E, Steel CM, Haites N, Scott RJ, Goldgar D, Neuhausen S, Daly PA, Ormiston W, McManus R, Scherneck S, Ponder BA, Ford D, Peto J, Stoppa-Lyonnet D, Bignon YJ, Struewing JP, Spurr NK, Bishop DT, Klijn JG, Devilee P, et al: Multifactorial analysis of differences between sporadic breast cancers and cancers involving BRCA1 and BRCA2 mutations. J Natl Cancer Inst 1998, 90:1138-1145.

32. Lakhani SR, van de Vijver MJ, Jacquemier J, Anderson TJ, Osin PP, McGuffog L, Easton DF: The pathology of familial breast cancer: predictive value of immunohistochemical markers estrogen receptor, progesterone receptor, HER-2, and P53 in patients with mutations in BRCA1 and BRCA2. J Clin Oncol 2002, 20:2310-2318.

33. Jiang $\mathrm{X}$, Castelao JE, Chavez-Uribe E, Fernandez Rodriguez B, Celeiro Muñoz C, Redondo CM, Peña Fernandez M, Novo Dominguez A, Pereira CD, Martínez ME, García-Caballero T, Fraga Rodriguez M, Antúnez J, Carracedo A, Forteza-Vila J, Gago-Dominguez M: Family history and breast cancer hormone receptor status in a Spanish cohort. PLoS One 2012, 7: e29459.

34. Lorenzo BJ, Hemminki K: Familial association of histology specific breast cancers with cancers at other sites. Int J Cancer 2004, 109:430-435.

35. Tutera AM, Sellers TA, Potter JD, Drinkard CR, Wiesner GL, Folsom AR: Association between family history of cancer and breast cancer defined by estrogen and progesterone receptor status. Genet Epidemiol 1996, 13:207-221. 
36. Ellberg C, Olsson $\mathrm{H}$ : Breast cancer patients with lobular cancer more commonly have a father than a mother diagnosed with cancer. BMC Cancer 2011, 11:497.

37. Martins FC, De S, Almendro V, Gönen M, Park SY, Blum JL, Herlihy W, Ethington G, Schnitt SJ, Tung N, Garber JE, Fetten K, Michor F, Polyak K: Evolutionary pathways in BRCA1-associated breast tumors. Cancer Discov 2012, 2:503-511.

38. Masciari S, Dillon DA, Rath M, Robson M, Weitzel JN, Balmana J, Gruber SB, Ford JM, Euhus D, Lebensohn A, Telli M, Pochebit SM, Lypas G, Garber JE: Breast cancer phenotype in women with TP53 germline mutations: a LiFraumeni syndrome consortium effort. Breast Cancer Res Treat 2012, 133:1125-1130.

39. Flanagan JM, Cocciardi S, Waddell N, Johnstone CN, Marsh A, Henderson S, Simpson P, da Silva L, KConFab Investigators, Khanna K, Lakhani S, Boshoff C, Chenevix-Trench G: DNA methylome of familial breast cancer identifies distinct profiles defined by mutation status. Am J Hum Genet 2010, 86:420-433.

doi:10.1186/bcr3248

Cite this article as: Dite et al:: Tumour morphology of early-onset breast cancers predicts breast cancer risk for first-degree relatives: the Australian Breast Cancer Family Registry. Breast Cancer Research 2012 14:R122.

\section{Submit your next manuscript to BioMed Central} and take full advantage of:

- Convenient online submission

- Thorough peer review

- No space constraints or color figure charges

- Immediate publication on acceptance

- Inclusion in PubMed, CAS, Scopus and Google Scholar

- Research which is freely available for redistribution

Submit your manuscript at www.biomedcentral.com/submit
Ciomed Central 